\title{
Improved integrated water management for agriculture in Upper East Region of Ghana
}

\author{
M.A. HAQUE, B. B. ALIGEBAM \& W. A. CALDERON \\ (M. A. H.: Water Resources Planning Organization, House No. 130, Road No. 1, Banani Dhaka- \\ 1213 Bangladesh; B. B. A.: CSIR-Savanna Agricultural Research Institute, Manga Station, P. $O$. \\ Box 46, Bawku, UER, Ghana; W. A. C.: INIA, Apartado Postal 592, Barquisimeto Edo Lara, \\ Venezuela)
}

\section{ABSTRACT}

The study gives an overview of the use of indigenous technical knowledge (ITK) and water management interventions in the Upper East Region (UER) of Ghana, and suggests research and development options to improve water management in the region. Water management practices were investigated in 16 villages in the region, using participatory methods and tools. Data were gathered in two phases: the first phase covered the use of ITK by farmers; and the second phase was an in-depth study into the use and management of interventions like dams, dugouts, and boreholes. During the study, the various stakeholders interviewed consisted of farmers and organisations such as governmental, non-governmental and research institutions with influence on water management. A typology of water management intervention in the study area was constructed. Resource flow, indicating the influence of interventions on internal and external flows within the crop-livestock-fishery system, was identified to create a clear understanding of the complex interactions within the system. Research and development options emerging from the analysis of the data were screened and prioritised to obtain the most suitable options for development. The chosen options indicated the importance of more effective use of available water as well as more efficient storage of water at the catchment level.

Original scientific paper. Received 28 Feb 03; revised 27 Feb 04.

\section{RÉSUMÉ}

Haque, M. A., Aligebam, B. B. \& Calderon, W. A.: Gestion d'eau intégrée et eméliorée pour l'agriculture de Upper East Region du Ghana. L'étude présente une vue d'ensemble de l'usage de Connaissance Technique Indigène (CTI) et les interventions de la gestion d'eau en Upper East Region (UER) du Ghana. Les options de recherche et développement pour améliorer la gestion d'eau dans la région sont suggérées. Les pratiques de la gestion d'eau étaient examinées en 16 villages dans la région en utilisant les outils et les méthodes participatives. La collecte de données était faite en deux phases, la première phase embrasse l'usage de CTl par les cultivateurs. La deuxième phase était une étude en profondeur de l'utilisation et la gestion d'interventions comme les barrages, les tranchées et les trous de sonde. Pendant l'étude, des diverses dépositaires d'enjeux comprenant les cultivateurs et les organisations telles que les gouvernementales, nongouvernementales et les institutions de recherche qui ont l'influence sur la gestion d'eau étaient interrogés. Une typologie d'intervention de la gestion d'eau dans la zone de l'étude était construite. L'écoulement de resource indiquant l'influence d'interventions sur les écoulements internes et externes dans le système culture-bétail-pêcherie était identifié de créer une compréhension précise d'interactions complexes dans le système. Les options de recherche et développement provenant de l'analyse de données étaient passées au crible et arrangée en priorité pour obtenir les options convenables pour le développement. Les options choisies indiquaient l'importance de l'utilisation plus efficace d'eau disponible ainsi que la conservation d'eau au niveau de captage hydrographique. 


\section{Introduction}

As in other developing countries in the world, smallholder farmers of Ghana are the backbone of agricultural production. The availability of water for irrigated agriculture and for drinking by the rural population is not always certain. Furthermore, the climate is characterised by a relatively short rainy season followed by several months of drought. Years with little rainfall or prolonged periods of drought during the rainy season can cause major problems in food production, and available water is not enough for animals. Tenural practices, population pressure, inefficient farming systems, and poor rainfall regime in the Upper East Region (UER) of Ghana have jointly created a fragile agricultural system. For a sustainable development process in the region, good management of natural resources, especially water for agriculture, is required.

An Irternational Centre for developmentoriented Research in Agriculture-The Netherlands field study (ICRA, 1999), centred on the improved integration of crop-livestock-fisheries systems in the irrigated and rainfed areas of the UER of Ghana, indicated clearly that water was the central development issue of the three sub-systems. The report stated that actions to increase water availability and prudent use of what is accessible are required. Based on six villages interviewed and other stakeholders in the regions, concerted action towards mitigating water stress emerged as a promising possibility. Some attempts at the individual farmer level to introduce harvesting interventions have met with varying degrees of success.

Several NGOs in the region have attempted introducing or enhancing water-harvesting techniques or both, but no agreement exists between the various NGOs on the most effective methods. The efforts of the Ministry of Food and Agriculture (MoFA) in this direction are largely limited to rehabilitating 19 per cent of the dams and dugouts in the area. Research has insufficient information on tested and tried water-harvesting methods suitable within the context of the farming system of the area. Old methods of soil and water conservation are practised on a limited scale. The effects of a generally worsening situation are seen in the drying up of formerly perennial water sources and decreasing livestock numbers in the region. The main stakeholders in the region strongly feel that something needs to be done to improve water management in the region.

\section{Objectives of the study}

The study had several specific objectives :

1. Identify the indigenous forms of water management for agriculture and analyze the strengths and weaknesses of the methods in representative areas of the three SubjectMatter Centres (SMCs) into which the Upper East Region is divided.

2. Identify exotic interventions in water management for agriculture and analyze the strengths and weaknesses of the methods in the study areas.

3. Analyze in detail the effects of the existing water management system on the croplivestock-fisheries systems in two of the six administrative districts of the region.

4. Identify and prioritize research and development options arising from the above objectives.

\section{Study area description}

Northern Ghana consists of three administrative regions: the Northern, Upper East and Upper West Regions. The UER is largely flat with gentle slope of less than 6 per cent and only a few uplands with more than 10 per cent slope (LACOSREP, 1990). The major sources of water in the Upper East Region are rivers, streams, groundwater, springs, and rainwater in natural ponds and lakes. The region lies in the Guinea Savannah ecological zone and has a very short rainy season from May to October, with an annual rainfall average of $1100 \mathrm{~mm}$. Water for domestic and agricultural activities is needed during the dry season. In the region, a total of 144 dams and 70 dugouts were constructed (Agongo, Dery \& Biggs, 1995). This 
was aimed at providing food security and regular income for the people who are among the poorest of the population of the country. Groundwater is used through boreholes and wells. Water is found in most wells, even in the dry season.

In the UER, the irrigated crops are rice in the lowland areas, and mainly vegetables on the upland areas (Agodzo, 1999). Some valleys within the irrigable areas of the small dams are used for rice cultivation during the rainy season, and for vegetable production during the dry season. The most widely used irrigation method in the UER is gravity irrigation from dams and normal irrigation with water from wells and streams. With irrigating from wells and streams, water is drawn manually with buckets, calabashes, or watering cans.

The major crops grown on the upland, rainfed soils are millet, sorghum and groundnuts. Minor crops include maize and cowpea. In the valley flood plains and irrigated areas, rice is grown during the rainy season and tomatoes and onions planted in the dry season. Agriculture is the main economic activity in the UER (Smilde, 1999). Livestock rearing is an integral part of the farming system. Cattle, donkeys, sheep, goats, pigs, and various kinds of poultry are kept. The soils in the region are characterised by low level of organic matter (less than $1 \%$ within the topsoil) and low nutrient status ( $\mathrm{P}, \mathrm{N}, \mathrm{Ca}, \mathrm{Mg}, \mathrm{K}$ and $\mathrm{Na}$ ), compared to the soils in the Afram Plains and the forest zone (LACOSREP, 1992).

The region has pronounced wet and dry seasons. In the wet season, the humidity is high $(91 \%)$. In the dry season, it decreases to 15 per cent during the day. Estimated potential water losses through evapo-transpiration are from 1.55 to $1.65 \mathrm{~m}$ per year (Smilde, 1999). Furthermore, although the conditions are suitable for the production of a single wet season crop, the uncertain dates for onset of planting rains, coupled with poor water-holding capacity of soils, places a premium on the timeliness of cultivation practices.

\section{Research approach: Agricultural research for development}

Sustainable agricultural development requires bottom-up approach. It should consider the farmers' needs and the interests of different stakeholders in the area. The International Centre for development-oriented Research in Agriculture (ICRA) promotes the Agricultural Research for Development (ARD) procedure, a bottom-up approach which examines farmers' problems, needs and interests. The procedure considers farmers and other stakeholders as equal partners in the process of technology development (Fig. 1). By this approach, resultant output from applied research can become more appropriate to conditions in the field; thus, improving the rate of adoption for the intended impact on livelihood.

The ARD procedure was followed to attain the objectives of the study. It is demand-driven and aids design of research relevant to resource-poor farmers and important needs of society. It aims at contributing towards poverty reduction, food

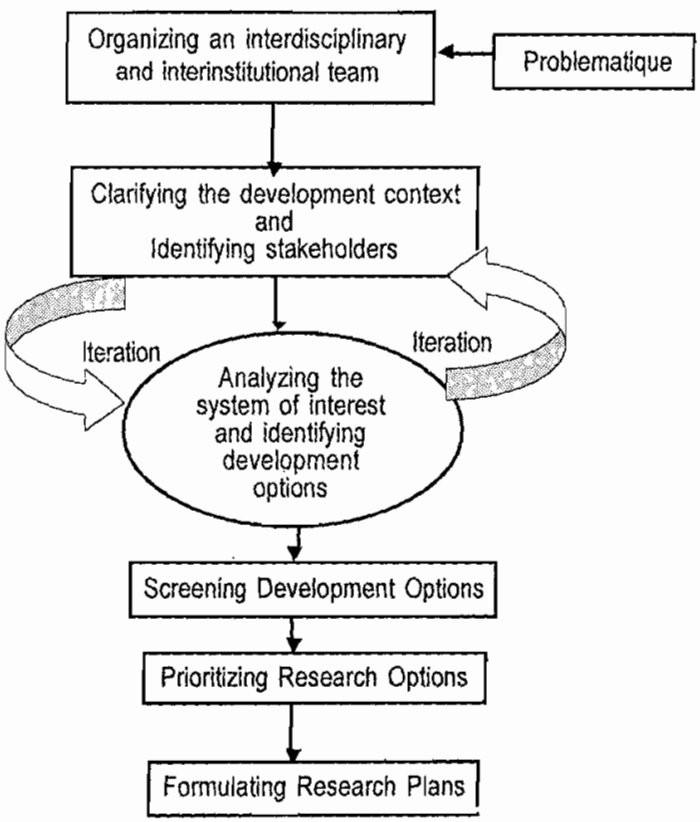

Fig. 1. Agricultural research for development (ARD) procedure. 
security, competitiveness of farming enterprises, and sustainable resource use. It is implemented by interdisciplinary teams, follows a participatory and systems approach, and integrates the perspectives of all relevant stakeholders. The ARD approach screens research options according to multiple development criteria. It is not a linear process, and certain aspects require several iterations for the final output.

\section{Data gathering}

Information was gathered in two phases from March to July 2000. For the first phase, information was gathered at the village level in the three SMCs. The second phase concentrated on the interventions and their influence at the village or household level. Sixteen villages, representing the three SMCs, were selected in the first phase. However, ITK, irrigation system, soil fertility, favourable and different cropping systems were also considered as criteria for selecting the villages. The study was conducted at the beginning of the rainy season to ensure that most farmers within the village or household were present at the meeting. A checklist was used for semi-structured interviews (SSI). Tools such as the time line, pair-wise ranking, transects, and historical maps were used to collect information about changes in different farming systems. With the help of local experts, 11 villages were selected in the second phase to meet criteria considered as having implications for the decision- making process within the household level. The mixed group interviewed consisted of old male and female farmers.

The typology was constructed after Phase I, and was based on general information on the different farming systems. It was constructed to highlight the diversity within a system being studied with a view to understanding how it functions. Production systems that function in the same way were grouped together, reflecting a similarity of objectives, strategies and limiting factors. The typology was constructed after defining categories and criteria that can be used to clearly separate different groups of farmers.

\section{Analysis of water management systems in UER}

\section{Typology regarding water management}

During the study, it became clear that great differences existed in water resources available to farming households. The availability of external water sources such as streams or rivers, or of structural interventions such as dams, dugouts, ponds and boreholes have significant impact on the livelihoods of farmers. These interventions create new opportunities for the community, and have a drastic impact on the socio-economic and biological resource flows in the system. As a first layer of distinction, the typology considered these differences. At the second level, it became very difficult to distinguish between different categories of farm types that solely depended on rainfall. In almost all households, all farming subsystems were present, although the degree of dependence on a particular system might differ.

\section{Crop-based farming system without external} water sources

For the crop-based farming system, it could be argued that the household may also have an animal component, but that crop production makes the largest contribution to the livelihood of the household. Such households can be found in rocky areas where grazing opportunities are very limited and water sources are very scarce. These communities make use of technologies such as stone bunding and terracing for water harvesting to improve the land for crop production. During the dry season, drinking water from wells or boreholes for human consumption is very scarce or can dry up, and watering of animals becomes a real problem.

\section{Integrated cropping system without external water sources}

The integrated cropping systems have more resources available that make keeping of livestock an important component of the farming system. 
Farmers in these areas have more grazing and water available for animals, but not enough water for irrigation. Some well or borehole water might be used for watering small gardens or fruit trees. Crops can only be grown during the rainy season.

\section{Crop production systems using external water sources}

These crop production systems are always near external water sources such as dams, dugouts, streams or rivers. These systems depend on rainwater during the rainy season, but can sustain crop production in the dry season due to the availability of irrigation water. Although some of the produce is consumed at home, most cash crops such as tomato, pepper, onion, and leafy vegetables are sold at the market. Although farmers may keep some livestock, it is an unimportant component of the farming system.

\section{Integrated farming systems with supplementary water sources}

In the integrated farming systems, the crop, livestock and fisheries sub-systems are truly integrated. Irrigated cash crops, rainfed crop production, as well as livestock play an important, although not necessarily equal part, in the livelihood of the family. Resource flows are closely interrelated and complicated as one system feeds into another. For water management, the systems make use of different kinds of ITK, and various forms of water management interventions are combined to make optimal use of water resources.

\section{Features of water sources}

A distinction can be made in sources of water within the crop-livestock-fisheries sub-systems in the irrigated and rainfed areas, especially for the cropping and fisheries sub-systems. No area in the UER is exclusively irrigated. Rainfed cropping co-exists with irrigated agriculture in areas with access to other water sources. The sources of water are in the area of the UER where crop-livestock-fisheries farming is practised. The two large irrigation projects, Tono and Vea, irrigate
1.1 per cent of the cultivated area in the UER. Farmers are allocated plots of $0.2-0.6$ ha in the project area. Cropping within these projects occurs on a year round basis. These projects have been developed on both sides of the river valley. The cropping areas are divided equally between upland and lowland areas. Crops grown in the upland plots include onion, tomato, millet, groundnut, sorghum, and maize. The lowland areas have been developed for rice production, and irrigation is by basin flooding.

The rural population is mainly dependent on dams and dugouts in the UER for dry season irrigation, livestock watering, and domestic purposes. Farmers often cultivate cash crops such as tomato, pepper and onion in the dry season with water from hand-dug wells. Rainwater is collected into ponds and used as fish ponds. No fishing activity takes place in the ponds during the dry season. Non-governmental organizations in the UER have constructed boreholes for domestic purposes. Besides, boreholes are used for watering small ruminants inside the compound house, and also for cattle when excess water runs from the boreholes into drinking troughs.

\section{Indigenous technical knowledge}

It was found in the 16 villages that the sources of ITK are handed down from generation to generation. Some ITK is also transferred from farmer to farmer at gatherings such as village-level farming festivals, and special invitations from chiefs to do the first or second weeding on their farming lands. Since the inception of the local extension services in the early 1980 s, farmers in some villages like Wurikambo have taken the opportunity to transfer ITK through night field schools organised with the help of extension technical officers.

Indigenous knowledge has various forms under the three sub-systems of farming:

\section{Contour identification}

Farmers identified the contours by using buckets or clay bowls to collect rainwater in the 
field. Where water collects equally indicates similar heights on that plot, and an approximate line is drawn to join them.

\section{Grass and stone bunding}

A grass bund is a row of grass planted along the contour, often in combination with a small earth bund or ridge. The grass acts as a barrier to slow down water run-off and intercept silt. Traditionally, different grass species were used for grass bunding, but after introducing Vertiver grass, it has been used almost exclusively. This robust species is very suitable for bunding, and its also used for various other purposes including thatching, mat and basket making, as well as feeding of animals during certain times. Although the type of grass has been changed by intervention, the indigenous knowledge for constructing bund properly is still in use.

Stone bunds are constructed along contours so that water will be evenly held behind the bund. The flow of run-off water is slowed down, allowing water time to infiltrate into the soil. Seepage of water through the bund is allowed to prevent breaching of the bund after heavy rain.

\section{Trash and earth bunding}

A trash bund is made by excavating a shallow ditch along the contour. Stalks are tied into bundles of 20 to $30 \mathrm{~cm}$ diameter and placed inside the ditch. The bundles are pegged to the ground so that they cannot be washed away. Rice or maize straw is added to the ditch, and earth is then spread over the top to form a slight ridge.

An earth bund is constructed on slopes by digging shallow ditches exactly along the contour and placing the soil on the downhill side to reduce the flow of run-off water. Earth bunding is also used for constructing rice field. It is used on its own when other materials like stones or grass are unavailable for making stone or grass bunds.

\section{Log bunding}

Logs from tree trunks are used for bunding purposes. Tree trunks are cut and placed across the contour slope to reduce run-off water and erosion. Particular tree species such as neem (Azadiracta indica) tree are used. These bunds are not very permanent, because trees rot over time.

\section{Mounding}

Mounds are made by raising the earth around the stem of plant; for instance, late millet plants or root crops like cassava. This increases water stored in the soil profile, and stored water helps to increase chances of survival during the drought period.

\section{Long beds}

Long beds are very similar to earth bunding, but they are larger (higher and wider) than the normal earth bunds. Because long beds are used in the UER for cultivating Frafra potato and other crops that prefer waterlogged conditions.

Traditional or ITK methods for water harvesting and conservation have been practised in most villages in the UER for a long time. Some villages without interventions to improve water management depend heavily on ITK for their agricuitural activities. Fig. 2 shows the number of villages out of the 16 interviewed, where the different ITKs are practised.

\section{Livestock watering and fishery system}

Indigenous technical knowledge also exists for watering livestock such as clay pots for collecting water from dams or wells and patios, and earth bunding for collecting rainwater. Farmers sometimes convert dugouts, resulting from moulding bricks, into fish ponds. Water collects in them and farmers stock them with fish. Such ponds are mostly found around rivers and streams, and sometimes around houses where women have scooped the topsoil for plastering.

\section{Water management interventions}

Interventions found in communities had several characteristics:

- purpose of the intervention 


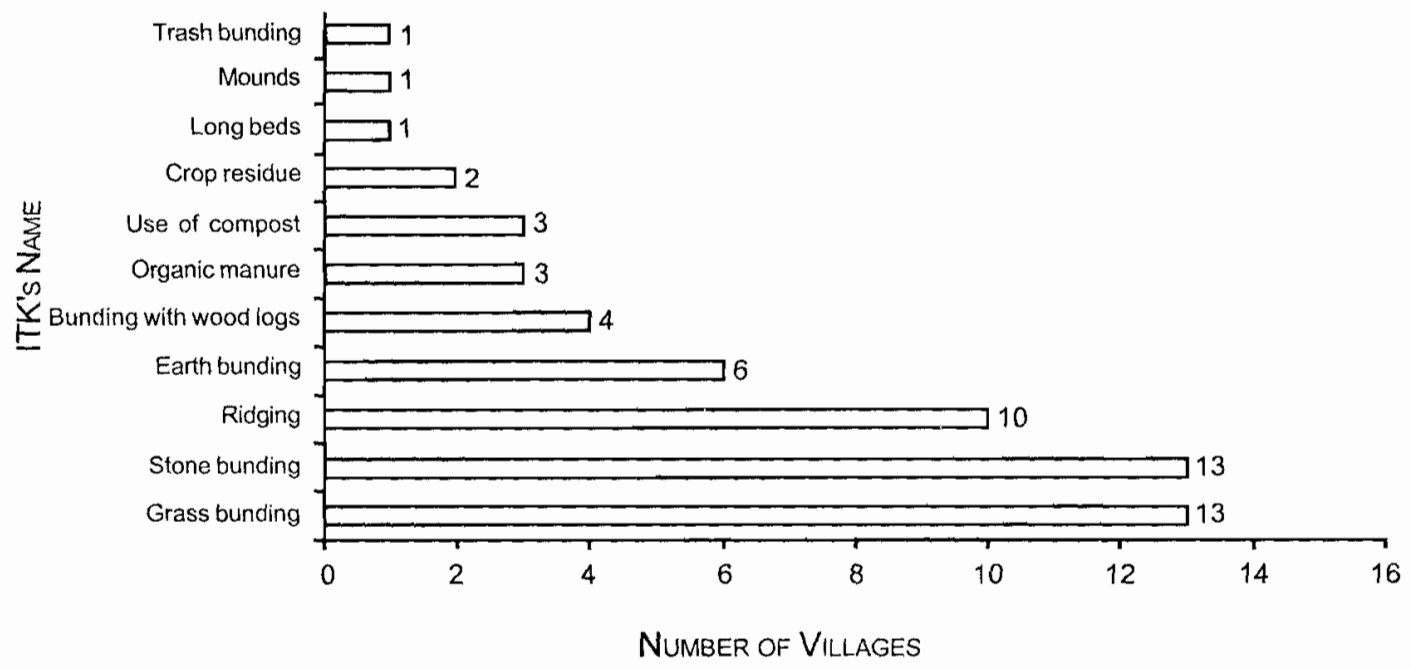

Fig. 2. Frequency of ITK's mentioned in 16 villages in the UER.

accessories that make the intervention work maintenance to be provided by the community how communities take decisions about them extent of community involvement when the intervention was introduced

- beneficiaries of different interventions Table 1 summarizes this information.

\section{Resource flow}

At the centre of the resource flow are the individual households within villages in the UER. As the resource flow indicates (Fig. 3), households depend on many resources in the surrounding environment, which have a crucial and specific role to play within the livelihood of each family.

In villages without interventions to improve water management, households depend on nearby streams or wells to provide water for drinking and domestic use. In communities that are fortunate enough to have water management interventions such as boreholes, dams, protected wells, ponds, and different bunding methods, more resources are available (Fig. 3). However, Tables 2 and 3 present the constraints and opportunities of ITK and interventions, respectively.

\section{Research and development options} Options for improvement

The analysis of indigenous technical knowledge and interventions on water management systems in the UER yielded resource flow, SWOT (Strengths, Weaknesses, Opportunities, and Threats) analysis (Table 2). Research options, development options, as well as research and development (R\&D) options emerged during the analytical process. Research options signify those for which no suitable technologies exist yet. Development options are those of a policy nature, or those for which suitable technologies already exist, but which are either absent or are of limited use in the region. Research and development options refer to options for which some technologies exist, but for which further research is required. Table 4 presents research options, development options, and R\&D options according to their relationship with water management.

\section{Conclusion}

It is clear that different forms of indigenous technical knowledge are used in the UER for water management. Recently, several organizations have introduced water management 
TABLE 1

Farmer Perceptions of Water Management Interventions

\begin{tabular}{|c|c|c|c|c|c|}
\hline $\begin{array}{l}\text { Interventions } \\
\text { Purpose }\end{array}$ & Accessories & Maintenance & $\begin{array}{l}\text { Decisions on } \\
\text { intervention }\end{array}$ & $\begin{array}{l}\text { Community } \\
\text { involvement } \\
\text { during } \\
\text { construction }\end{array}$ & Benefits \\
\hline Dams & $\begin{array}{l}\text { Spillways } \\
\text { Valves } \\
\text { Main canal } \\
\text { Laterals } \\
\text { Pipes } \\
\text { Rubber hoses } \\
\text { Tunnels }\end{array}$ & $\begin{array}{l}\text { Water users } \\
\text { associations (WUA) }\end{array}$ & $\begin{array}{l}\text { Government } \\
\text { Chief consulted }\end{array}$ & $\begin{array}{l}\text { Labour } \\
\text { Food (for } \\
\text { construction/ } \\
\text { rehabilitation } \\
\text { teams) }\end{array}$ & $\begin{array}{l}\text { Livestock farmers } \\
\text { Crop farmers } \\
\text { Fishermen } \\
\text { Road building } \\
\text { contractors } \\
\text { House building }\end{array}$ \\
\hline Wells & $\begin{array}{l}\text { Covers } \\
\text { Cemented walls } \\
\text { Watering troughs }\end{array}$ & $\begin{array}{l}\text { Sectional } \\
\text { committees } \\
\text { consisting of } \\
\text { households } \\
\text { sharing of well }\end{array}$ & The community & $\begin{array}{l}\text { Labour } \\
\text { Food (for } \\
\text { construction } \\
\text { teams) }\end{array}$ & $\begin{array}{l}\text { Households } \\
\text { Livestock farme! } \\
\text { (small ruminants } \\
\text { sheep, goats, } \\
\text { poultry) } \\
\text { Gardeners }\end{array}$ \\
\hline Boreholes & $\begin{array}{l}\text { Hand pumps } \\
\text { Cemented walls } \\
\text { Drinking troughs }\end{array}$ & $\begin{array}{l}\text { Village development } \\
\text { committees such as } \\
\text { Community } \\
\text { water organizer (CWO) } \\
\text { in the case of Yisobsa }\end{array}$ & $\begin{array}{l}\text { In the past } \\
\text { chiefs, elders in } \\
\text { community } \\
\text { At present, the } \\
\text { community } \\
\text { takes decisions }\end{array}$ & $\begin{array}{l}\text { Previously no } \\
\text { contribution } \\
\text { Currently } \\
\text { cash or } \\
\text { material } \\
\text { (stones, sand, } \\
\text { cement) } \\
\text { Labour }\end{array}$ & $\begin{array}{l}\text { Whole communit; } \\
\text { Livestock farmetr } \\
\text { (small ruminants } \\
\text { sheep, goats, } \\
\text { poultry) } \\
\text { Gardeners }\end{array}$ \\
\hline Dugouts & None & None & $\begin{array}{l}\text { Community } \\
\text { elder }\end{array}$ & $\begin{array}{l}\text { Labour } \\
\text { Food }\end{array}$ & Vegetable farmers \\
\hline Ponds & $\begin{array}{l}\text { Valves- } \\
\text { inlet/outlet }\end{array}$ & $\begin{array}{l}\text { Fishermen/ } \\
\text { Fish farmers }\end{array}$ & $\begin{array}{l}\text { Fisheries } \\
\text { Department }\end{array}$ & $\begin{array}{l}\text { Labour } \\
\text { Food }\end{array}$ & $\begin{array}{l}\text { Fishermen/ } \\
\text { Fish farmers }\end{array}$ \\
\hline
\end{tabular}

interventions, in the region. In communities endowed with different water management interventions, much more resources are available than in those without interventions. These interventions create new opportunities for the community, and have a drastic impact on socioeconomic and biological resource flows in the system.

The options represent possible areas of intervention towards improving water management in the UER. The amount of rainfall received is not a limiting factor, but too much of it is lost in the region through excessive run-off. Regardless of how many water sources are made available to farmers, water will still be wasted if it is not used more effectively. Water management can, however, also be improved on the farm level and in the household by more effective storage and use (micro-level management).

The choice of options reflect the macro and micro-levels of management, as it emphasises more efficient damming of waterways as well as rehabilitating and upgrading current water bodies. Options that promote better management on the 


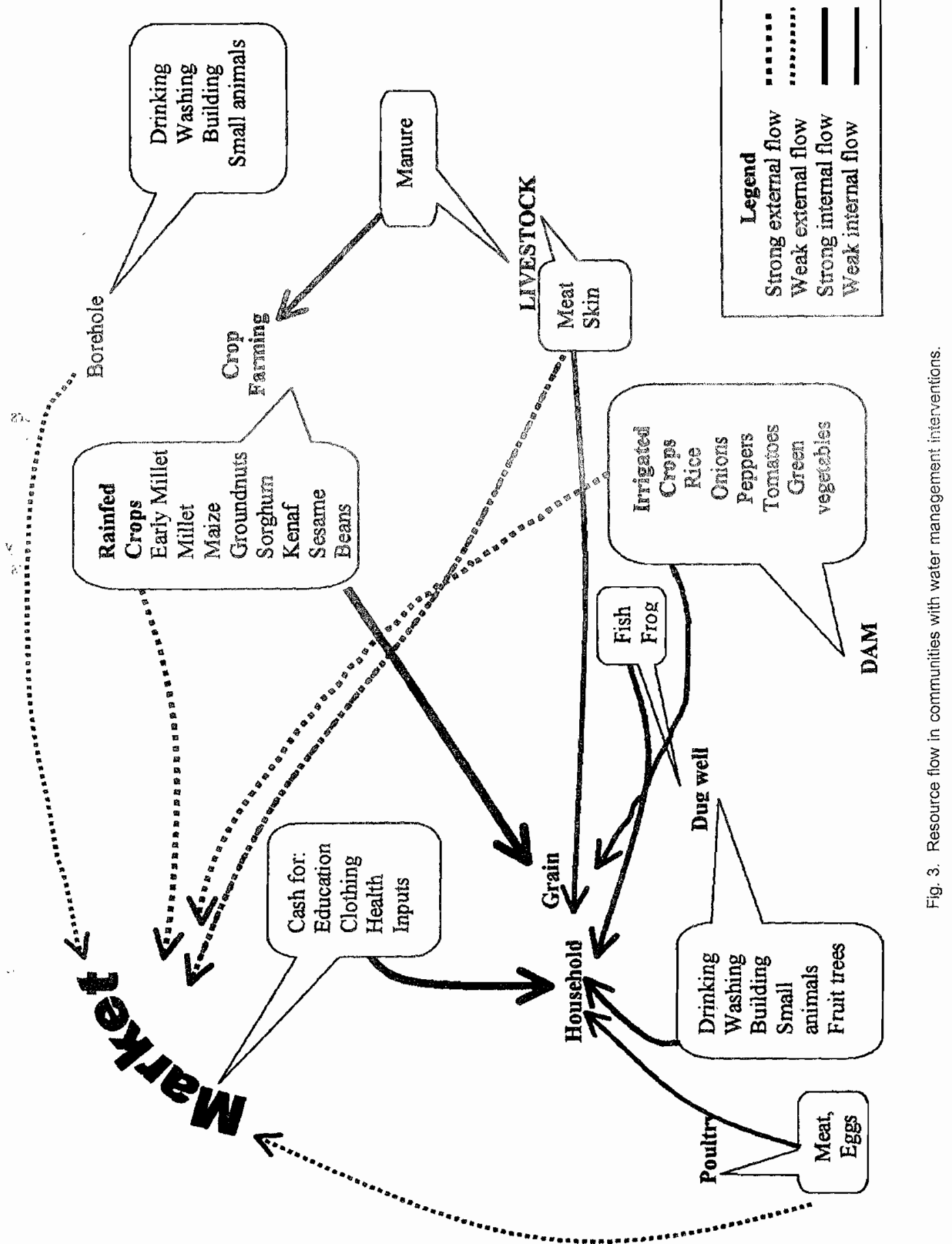


M. A. Haque et al. (2005) Ghana Jn/ agric. Sci. 38, 29-42.

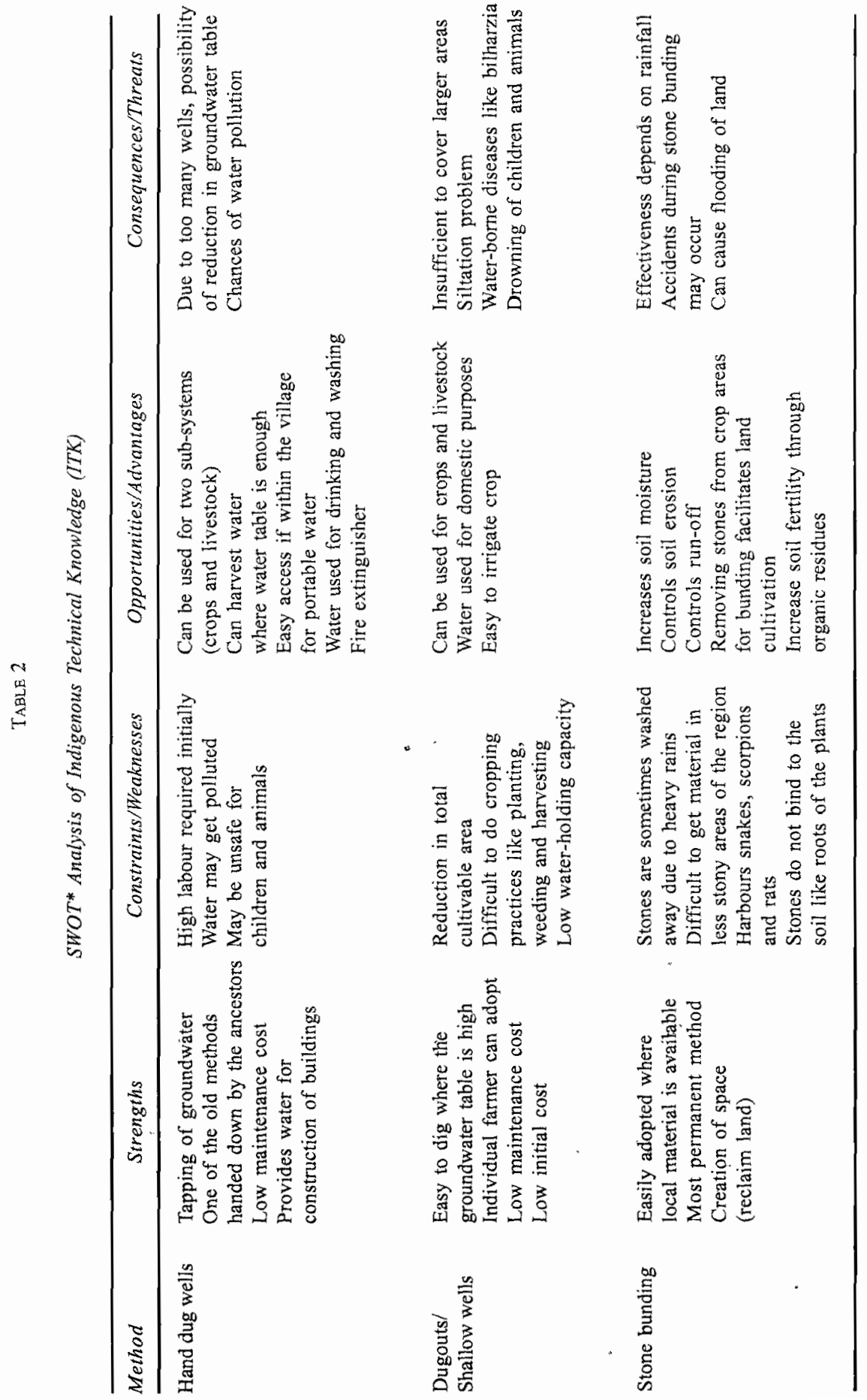




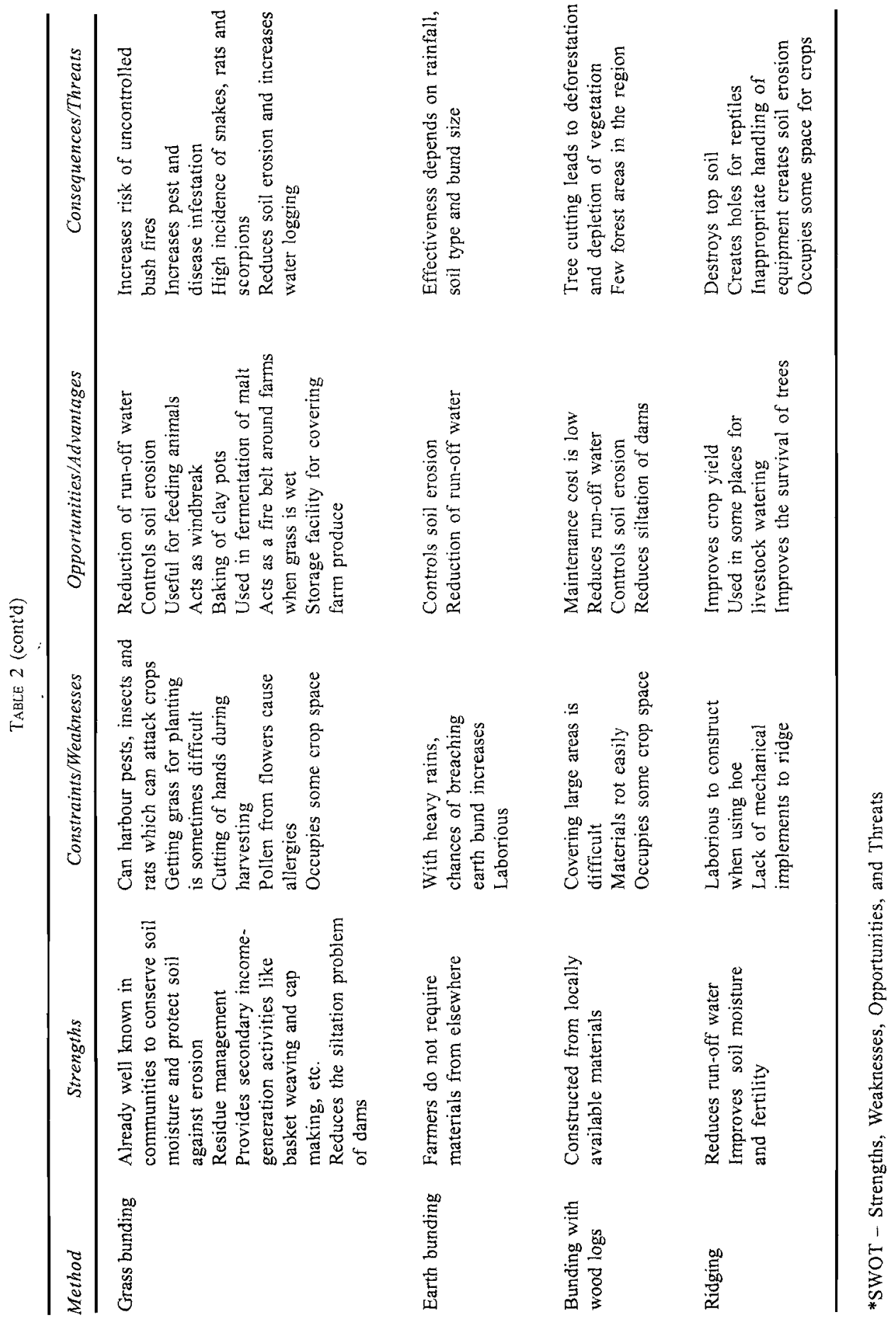




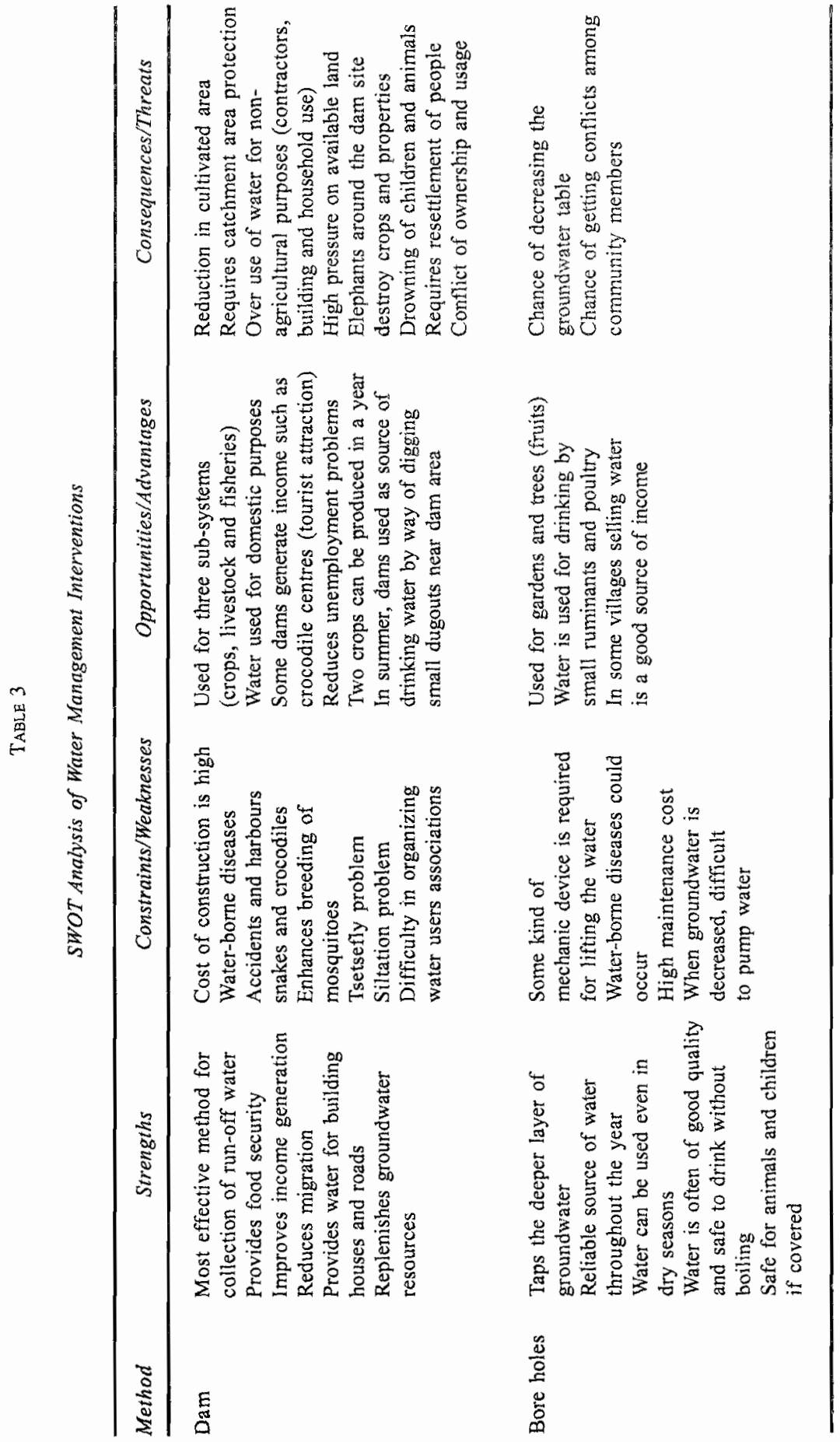


TABLE 4

Research Options, Development Options, and Research and Development ( $R \&$ D) Options According to their Relationship with Water Management

$\begin{array}{llrl}\text { Type of option } & \text { Research options } & \text { Development options } & \text { Research and development } \\ (R \text { \& } D) \text { options }\end{array}$

\begin{tabular}{ll}
\hline Options directly & Research into efficient \\
related to water & water use for dry \\
management & season gardening
\end{tabular}

Reinforcement of bunds

Methods to improve catchment management Upgrading of dugouts and rehabilitation of dams

Damming of waterways

Promotion of drip irrigation methods in small-scale vegetable production Micro-irrigation schemes using tube wells Improve soil water management

Options indirectly related to water management
Tomato varieties with longer shelf life Research on sustainable fodder species
Water management and fish production improved by promotion of fishermen's organizatrons
Integrated desiltation of dams Harvesting of rainwater
Improvement of livestock feeding through production of small-scale bale and silage making Introduction of protein fodder banks with water supply in pilot communities
Options not related but with possible future impact
Improve marketing of agricultural produce in the UER

Develop common platform for stakeholders to meet and discuss water management issues micro-level, like harvesting techniques and microdrip irrigation methods, are also included. The chosen options suggest that solutions for improved water management not only lie in engineering and technical interventions, but also in the contributions of farmers, the water they use, and protection of catchment. The cost of suggested technologies vary from low-cost bunding methods (local material and labour) to expensive upgrading of water bodies with price tags of millions of dollars. All the options presented will have equal benefits or increased benefits for women with a crucial role to play in managing water bodies in the region.

\section{Acknowledgement}

This study was supported by funds provided by the International Centre for development-oriented 
Research in Agriculture (ICRA), The Netherlands. The authors gratefully acknowledge staff of Ministry of Food and Agriculture (MoFA), Upper East Region, Ghana, for their technical assistance.

\section{REFERENCES}

Agodzo, Y. (1999) A field survey report on soil and water resources of Ghana: Their conservation, management and constraints to their utilisation for sustainable development. Topics appl. Resour. Mgmt $3,145-160$.

Agongo, P., Dery, A. B. \& Biggs (1995) Soil erosion and conservation in the Northern and Upper Regions of Ghana. Topics appl. Resour. Mgmt 2, $135-157$.

ICRA (1999) Towards sustainable agricultural development. International Centre for developmentoriented Research in Agriculture. Field Study Report. Working Document Series 77. Ghana.

LACOSREP (1990) Appraisal Report. Vol. 2. Working Papers. Report No. 0244-GH. Upper East Region Land Conservation and Smallholder Rehabilitation Project.

LACOSREP (1992) Development Consultants Associates. Report No. 0125 - GH. Base Line Study Report: Upper East Region Land Conservation and Small Holder Rehabilitation Project.

Smilde, L. (1999) Dry season water study into the performance of the Busongo Dam near the village of Sirigu, Upper East Region, Ghana. (M Sc Thesis). Wageningen Agric. University, The Netherlands. 